\title{
KARAKTERISTIK LAHAN DAN KOMPOSISI JENIS TANAMAN PENYUSUN AGROFORESTRY DI KECAMATAN SESEAN KABUPATEN TORAJA UTARA
}

\section{LAND CHARACTERISTICS AND PLANT COMPOSITIONS OF AGROFORESTRY IN SESEAN DISTRICT, TORAJA UTARA REGENCY}

\author{
Budirman Bachtiar ${ }^{1}$ dan Ratu M. Sandabunga ${ }^{2}$ \\ 1. Staf Pengajar, Fakultas Kehutanan, Universitas Hasanuddin, Makassar \\ 2 Mahasiswa Kehutanan Laboratorium Silvikultur dan Fisiologi Pohon, \\ Fakultas Kehutanan, Universitas Hasanuddin, Makassar \\ Corresponding author : budi pesan@yahoo.com
}

\begin{abstract}
Abstrak
Sistem agroforestri akhir-akhir ini dikembangkan oleh masyarakat untuk memenuhi kebutuhannya. Namun masih banyak masyarakat yang belum memahami untuk memilih tanaman yang sesuai pada lahan agroforestri. Penelitian ini bertujuan untuk mengetahui karakteristik lahan dan komponen agroforestri di Kecamatan Sesean Kabupaten Toraja. Penelitian ini dilakukan dengan cara membandingkan kebutuhan tanaman dan karakteristiknya di lahan. Tanaman di lokasi penelitian adalah kopi robusta, kakao, pisang, manggis, buangin, aren, bambu betung, dan uru. Hasil penelitian menunjukkan kesesuaian lahan tanaman dari cukup sesuai (S2) sampai dengan sesuai marginal (S3). Faktor pembatas yang membatasi pertumbuhan tanaman didominasi oleh curah hujan dan juga suhu, namun kedua faktor pembatas tersebut sulit dan tidak dapat diperbaiki.
\end{abstract}

Kata Kunci: Agroforestry, Karakteristik Lahan, Tanaman

\begin{abstract}
Agroforestry system recently developed by the community to meet their needs. But many people's don't understand yet to select suitability plants on the agroforestry land. This study aims to determine the land characteristics and components of agroforestry in District Sesean, Toraja District. This research caried out in the way comparethe requireiment of plants and charactristic at land. Plants in research location are robusta coffee, cocoa, banana, mangosteen, buangin (pine mountain), aren, bamboo betung, and uru. The result of research indicated land suitability of plants are moderately suitable (S2) to marginal suitable (S3). Limitation factors that limit plant growth is predominantly rainfall and also temperature, but both of these limiting factors are difficult and can not be repaired.
\end{abstract}

Keywords : Agroforestry, Land characteristics, Plants 


\section{Pendahuluan}

Agroforestry merupakan sistem pengelolaan lahan yang ditawarkan guna mengatasi permasalahan yang timbul akibat pemanfaatan lahan yang tidak tepat dan sekaligus mengatasi masalah pangan (Hairiah, dkk,. 2003). Seiring dengan meningkatnya jumlah penduduk maka peningkatan permintaan akan pangan, produk pertanian dan non pertanian juga semakin meningkat.

Sistem agroforestry ini sudah mulai dikembangkan dan dipraktekkan oleh masyarakat untuk menghasilkan kayu dan bahan pangan untuk peningkatan kesejahteraan keluarga mereka. Pengamatan di lapangan menunjukkan adanya ketidak sesuaian di dalam pemilihan jenis tanaman dengan karakteristi lahan yang dimiliki oleh petani. Kesalahan dalam pemilihan jenis tanaman dapat menimbulkan kerugian, karena tidak semua jenis tumbuhan dapat tumbuh baik pada suatu lahan jika tidak diketahui tingkat kesesuaian lahannya (Handayani dan Sudomo, 2004).

Berdasarkan hal tersebut maka penerapan agroforestry perlu didekati dari segi evaluasi lahannya. Evaluasi kesesuaian lahan adalah membandingkan karakteristik lahan yang dimiliki oleh lahan yang digunakan dengan persyaratan yang diminta oleh tipe penggunaaan lahan yang diterapkan. Dengan cara ini, maka akan diketahui potensi lahan atau kelas kesesuaian lahan dengan jenis tanaman yang akan dikembangkan pada lahan tersebut. Pemanfaatkan lahan secara tepat dan berkelanjutgan serta untuk menghindari resiko penurunan produktifitas lahan, maka diperlukan pendekatan evaluasi kesesuaian lahan (Tufaila, dkk., 2014).

Masyarakat Toraja Utara sudah sejak lama telah melakakukan prektek pertanian tradisional termasuk praktek-praktek agroforestry. Masyrakat Toraja khususnya masyarakat di Kecamatan Sesean merupakan salah satu wilayah di Kabupaten Toraja Utara yang menerapkan sistem agroforestry untuk memenuhi kebutuhannya. Namun karena pemilihan jenis tanaman penyusun komponen agroforestry lebih banyak didasarkan pada pertimbangan ekonomi dan mempertimbangkan karakteristik lahannya, maka hal inilah yang melatarbelakangi penelitian ini yaitu untuk memberikan informasi mengenai evaluasi karakteristik lahan dan kesesuaiannya dengan komponen agroforestry di Kecamatan Sesean, Kabupaten Toraja utara.

\section{Metode Penelitian}

Penelitian ini dilaksanakan pada bulan Maret sampai April 2018. Penelitian ini dilakakan melalui dua tahapan kegiatan yaitu pengamatan dan pengukuran di lapangan dan analisis tanah laboratorium. Alat yang digunakan dalam penelitian ini antara lain GPS, tali rapiah, roll meter, pita meter, haga meter, cangkul, sekop, plastic bening, kertas label, kamera, alat-alat laboratorium dan tabel kualitas dan karakteristik lahan. Bahan yang digunakan dalam penelitian ini adalah data iklim, sampel tanah untuk analisis di laboratorium, dan bahan-bahan laboratorium untuk analisa tanah.

\section{Tahap Persiapan}

Tahap persiapan meliputi pengumpulan data yang berkaitan dengan penelitian, seperti penelaahan pustaka, melengkapi alat-alat yang akan digunakan dalam penelitian, melaksanakan survei pendahuluan untuk memastikan lokasi yang menerapkan pola agroforestry dan penyajian data iklim yang diambil dari Badan Meteorologi dan Klimatologi (BMKG). 


\section{Tahap Pengamatan Jenis Tanaman dan Pengambilan Contoh Tanah di Lapangan}

Plot pengamtan dipilih secara purposive dan ditempatkan pada kebun masyarakat yang menerapkan sistem agroforestry yang memiiki jenis tanaman yang cukup beragam. Adapun pengamatan yang dilakukan di lapangan yaitu (1) menginventarisir jenis tanaman komponen penyusun agroforestry, (2) mengamati karakteristik tahan dan mengambil contoh tanah untuk dianalisis di laboratorium. Pengambilan contoh tanah dilakukan secara komposit untuk penilaian sifat kimia dan fisika tanah. Karakteristik tanah yang diamati pada penelitian ini yaitu lereng, drainase, kedalaman tanah, batuan permukaan, singkapan batuan, tekstur, kapasitas tukar kation, $\mathrm{pH}, \mathrm{N}$ total, $\mathrm{P}_{2} \mathrm{O}_{5}$ dan $\mathrm{K}_{2} \mathrm{O}$ tersedia.

Adapun plot yang dibuat saat di lapangan yaitu berukuran $50 \mathrm{~m} \times 20 \mathrm{~m}$. Kemudian contoh tanah diambil dibeberapa titik yaitu 5 titik. Penempatan setiap titik berada di sudut plot dan satu titik berada di tengah-tengah plot atau secara diagonal (Gambar 1). Contoh tanah diambil pada kelima titik tersebut dengan cangkul dan bor tanah, pada masing-masing kedalaman 0-30 $\mathrm{cm}$ dan $30-60 \mathrm{~cm}$, sedangkan untuk pembuatan profil tanah dibuat dengan dengan ukuran $100 \mathrm{~cm} \times 100 \mathrm{~cm} \times 150 \mathrm{~cm}$. Profil tanah dibuat pada titik tengah plot. Selanjutnya contoh tanah yang telah diambil dikompositkan dan dimasukkan ke dalam plastik bening untuk analisis tanah di laboratorium.

$20 \mathrm{~m}$

$50 \mathrm{~m}$

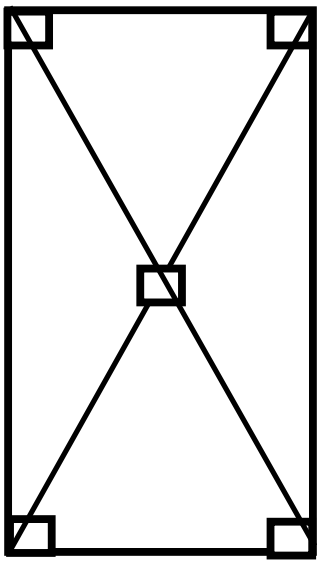

Gambar 1. Model Pengambilan Sampel Tanah

\section{Tahap Analisis Laboratorium}

Analisis sifat kimia dan fisik tanahnya. dilakukan dengan cara menganalisis contoh tanah yang telah diambil dari lapangan di Laboratorium Silvikultur dan Fisiologi Pohon Fakultas Kehutanan dan Laboratorium Kimia dan Kesuburan Tanah Fakultas Pertanian Universitas Hasanuddin.

\section{Tahap Akhir}

Berdasarkan data karakteristik lahan yang diperoleh dari hasil pengamatan lahan di lapangan dan analisis tanah di laboratorium maka dilakukan penilaian status kesesuaian lahan. Status kesesuaian lahan dilakukan dengan menggunakan metode pencocokan (Matching) antara data karakteristik lahan yang telah ditentukan nilainya dengan kriteria persyaratan tumbuh tanaman. 


\section{Hasil dan Pembahasan}

\section{Deskripsi Lokasi Penelitian}

Secara geografis lokasi penelitian berada pada koordinat $02^{\circ} 55^{\prime} 22,7^{\prime \prime}$ LS dan $119^{\circ} 56^{\prime} 18,5^{\prime \prime}$ BT. dengan ketinggian $867 \mathrm{~m}$ dpl. Topografi melandai/bergelombang dengan curah hujan yang tinggi yaitu rata-rata sebesar 4.222,5 mm/tahun dan suhu rata-rata $21,5^{\circ} \mathrm{C}$. Karakteristik tanahnya yaitu termasuk jenis tanah ultisol dangan $\mathrm{pH}$ yang masam dan tekstur agak halus.

\section{Karakteristik Lahan Lokasi Penelitian}

Curah hujan di lokasi penelitian diperoleh dari stasiun klimatologi. Data tersebut merupakan data curah hujan bulanan selama 10 tahun terakhir (2008 - 2017) pada stasiun penakar curah hujan terdekat dengan lokasi penelitian. Dari hasil perhitungan dapat diketahui bahwa curah hujan rata-rata tahuanan di lokasi penelitian yaitu sebesar $4.222,5$ $\mathrm{mm} / \mathrm{tahun}$.

Suhu udara di lokasi penelitian dapat diketahui dengan memperkirakannya berdasarkan ketinggian tempat dari permukaan laut. Suhu udara rata-rata dapat dihitung dengan menggunakan rumus Braak (1928) :

$$
26,3^{\circ} \mathrm{C}-\left(0,01 \times \text { elevasi dalam meter } x 0,6^{\circ} \mathrm{C}\right) \text {, }
$$

dimana ketinggian lokasi penelitian yaitu $876 \mathrm{~m}$ di atas permukaan laut jadi suhu rata-rata tahunan adalah $21,05^{\circ} \mathrm{C}$.

Kualitas lahan ialah sifat-sifat lahan yang tidak dapat diukur secara langsung karena merupakan interaksi dari beberapa karakteristik lahan yang mempunyai pengaruh nyata terhadap kesesuaian lahan untuk penggunaan-penggunaan tertentu (Hardjowigeno dan Widiatmaka 2007). Karakteristik lahan adalah sifat lahan yang dapat diukur atau diestimasi. Karakteristik lahan ini digunakan untuk evaluasi lahan bagi komoditas tertentu (Djaenudin, dkk., 2003). Data karakteristik lahan pada lokasi penelitian yang diukur untuk kesesuaian lahan tersaji pada Tabel 1.

Tabel 1. Kualitas/Karakteristik Lahan Lokasi Penelitian

\section{Persyaratan Penggunaan Lahan/Karakteristik Lahan \\ Nilai Data}

Regim Suhu ( $\mathrm{t}$ )

1. Suhu tahunanan $\left({ }^{\circ} \mathrm{C}\right)$

Ketersediaan Air (w)

1. Bulan Kering $(<75 \mathrm{~mm})$

2. Curah hujan tahuanan $(\mathrm{mm})$

Jerakaran ( $r$ )

1. Drainase

2. Tekstur

$21,05^{\circ} \mathrm{C}$

2,3 Bulan

$4222,5 \mathrm{~mm} /$ tahun

3. Kedalaman Efektif $(\mathrm{cm})$

Retensi Hara (f)

1. KTK

2. $\mathrm{Ph}$

Baik

SCL (Lempung Liat berpasir)

$143 \mathrm{~cm}$

Ketersediaan Hara (n)

1. $\mathrm{N}$ total

2. $\mathrm{P}_{2} \mathrm{O}_{5}$ tersedia

3. $\mathrm{K}_{2} \mathrm{O}$ tersedia

Terrain (s)

1. Kemiringan Lahan (\%)

2. Batuan Permukaan

3. Singkapan Batuan

28,63 dan 26,84 (Tinggi)

5,37 dan 5,35

$0,32 \%$ dan $0,29 \%$ (Sedang)

20,7ppm dan 21,7ppm (Tinggi)

$0,45 \mathrm{me} / 100 \mathrm{gr}$ dan $0,36 \mathrm{me} / 100 \mathrm{gr}$

(Sedang)
$13.5 \%$

0

0 
Regim Suhu (suhu tahunan) merupakan kualitas/karakteristik lahan yang mempengaruhi pertumbuhan dan produktivitas tanaman. Pada Tabel 1 terlihat bahwa suhu tahunan di lokasi penelitian yaitu $21,05^{\circ} \mathrm{C}$.

Ketersediaan air merupakan kualitas lahan yang memiliki dua karakteristik lahan yaitu bulan kering $(<75 \mathrm{~mm})$ dan curah hujan tahunanan $(\mathrm{mm})$. Data bulan kering didapatkan dari curah hujan selama 10 tahun terakhir yang jumlahnya $<75 \mathrm{~mm} /$ bulan (Wibowo 2008). Dari hasil perhitungan bulan kering yang jumlahnya $<75 \mathrm{~mm}$ dapat diketahui jumlah bulan kering $(<75 \mathrm{~mm})$ di lokasi penelitian adalah 2,3 bulan. Curah hujan merupakan unsur iklim yang berperan paling besar dalam menentukan tingkat produktivitas suatu tanaman (Bey dan Las, 1991). Sedangkan untuk nilai dari curah hujan tahunan rata-rata yaitu sebesar $4.222,5 \mathrm{~mm} /$ tahun.

Media perakaran, kualitas lahan yang terdiri atas karakteristik lahan berupa drainase pada lokasi penelitian termasuk dalam kategori baik. Drainase tanah pada lokasi penelitian dapat diketahui kondisinya dengan mengamati ada tidaknya genangan air atau ada tidaknya warna kelabu atau bercak karatan pada lapisan tanah lahan penelitian. Tekstur tanah menunjukkan perbandingan relatif tiga fraksi partikel dalam suatu massa tanah, yaitu pasir, debu, dan liat (Setianingrum, 2011). Nilai persentase ketiga fraksi tanah disajikan pada Tabel 2.

Tabel 2. Nilai Persentase Fraksi Tanah

\begin{tabular}{rrrrr}
\hline No. & \% Debu & \% Liat & \multicolumn{2}{c}{$\%$ Pasir } \\
\hline 1 & 41.45 & 54.10 & & 4.44 \\
\hline 2 & 30.05 & 53.32 & & 16.63 \\
\hline
\end{tabular}

Tabel 2 menunjukkan bahwa pada kedalaman 0-30 cm nilai untuk debu $(41,45 \%)$, liat $(54,10 \%)$, dan pasir 4,44\%. Sedangkan pada kedalaman 30-60 cm berturut-turut debu $(30,05 \%)$, liat $(53,32 \%)$, dan pasir $(16,63 \%)$. Dari hasil analisis tekstur di atas menunjukkan bahwa tekstur tanah pada lokasi penelitian adalah lempung liat berpasir (SCL).

Kedalaman efektif pada lokasi penelitian dapat diketahui dengan membuat profil tanah sampai sejauh mana akar menembus tanah (Hardjowigeno dan Widiatmaka, 2007). Berdasarkan hasil pengamatan dan pengukuran di lapangan diketahui bahwa kedalaman efektif lokasi penelitian termasuk kategori dalam yaitu $143 \mathrm{~cm}$. Berdasarkan kriteria USDA kedalaman efektif lebih besar dari $90 \mathrm{~cm}$ termasuk kategori dalam (Klingebiel \& Montgomery, 1961). Kedalaman tanah seperti ini mampu mendukung pertubumhan tanaman dengan baik karena akarnya dapat tumbuh dan berkembang dengan baik.

Retensi hara merupakan kualitas lahan yang ditentukan dengan karakteristik lahan Kapasitas tukar kation (KTK) berdasarkan hasil analisis nilai KTK pada Tabel 1 ketahui bahwa nilainya yaitu 28,63 me/100 g - 26,84 me/100 g dari 2 kedalaman yaitu $30 \mathrm{~cm}$ dan 60 $\mathrm{cm}$. Kedua kedalaman memiliki nilai KTK yang tidak berbeda jauh berdasarkan klasifikasi kelas KTK menurut Mukhlis, 2007 dapat diketahui bahwa tanah pada lokasi penelitian nilai KTK yang dimiliki masuk dalam kelas Tinggi. Dimana menurut Mukhlis, (2007) Nilai KTK tanah yang besar sangat menentukan tingkat kesuburan tanah.

$\mathrm{pH}$ merupakan salah satu parameter penting suatu tanaman dapat tumbuh atau tidak. Kandungan $\mathrm{pH}$ tanah pada lokasi penelitian berdasarkan Tabel 1 dari dua kedalaman yaitu 5,37 dan 5,35. Menurut Djaenudin, dkk.,(2003) klasifikasi kandungan pH tanah tersebut termasuk klasifikasi yang masam.

Ketersediaan hara kualitas lahan dengan karakteristik lahannya yaitu $\mathrm{N}$ total Nitrogen dibutuhkan oleh tanaman dalam jumlah yang besar, umumnya menjadi faktor pembatas pada tanah-tanah yang tidak dipupuk. Posfor merupakan salah satu unsur makro yang sangat penting bagi pertumbuhan tanaman tetapi kadarnya di dalam tanaman lebih rendah dari $\mathrm{N}$ dan K. Secara umum kalium diabsorpsi oleh tanaman dalam bentuk $\mathrm{K}_{+}$, dan dijumpai dalam berbagai kadar di dalam tanah (Sanchez, 1993). Berdasarkan analisis di laboratorium dapat diketahui bahwa nilai $N$ total pada lokasi penelitian yaitu $0,32 \%$ dan $0,29 \%$ berdasarkan perhitungan dari Kjedahl. Kelas klasifikasi $\mathrm{N}$ total menurut CSR/FAO, 1983 
yaitu $\mathrm{N}$ totalnya Sedang. Nilai $\mathrm{P}_{2} \mathrm{O}_{5}$ tersedia berdasarkan hasil analisis pada tabel 10 yaitu 20,7 ppm dan 21,1 ppm dan termasuk dalam kategori Tinggi. Sementara untuk $\mathrm{K}_{2} \mathrm{O}$ tersedia hasil analisis tanah pada lokasi penelitian yaitu $0,45 \mathrm{me} / 100 \mathrm{~g}$ dan $0,36 \mathrm{me} / 100 \mathrm{~g}$, dimana kriteria kelas dari $\mathrm{K}_{2} \mathrm{O}$ adalah sedang.

Terrain atau potensi mekanisasi, kualiatas lahan yang terdiri dari karakteristik kemiringan lahan, besar kecilnya kemiringan lereng menentukan kemudahan penggarapan tanah. Berdasarkan hasil pengamatan di lokasi penelitian didapatkan kemiringan lerengnya sebesar $13,5 \%$. Batuan permukaan dan singkapan berdasarkan pengamatan di lapangan dapat ketahui bahwa tidak terdapat atau sedikit batuan atau nilainya 0 yang artinya menutupi kurang dari $0,01 \%-0,1 \%$ dari luas permukaan tanah. Keadaan batuan yang terdiri batuan permukaan dan singkapan ini merupakan aspek yang mempengaruhi pengelolaan serta mempengaruhi pertumbuhan tanaman (Setianingrum, 2011).

\section{Komposisi Jenis Tanaman dan Kesesuaian Lahan}

Komposisi jenis tanaman yang ditanam dan dikembangkan oleh masyarakat pada lokasi penelitian yaitu kopi robusta, kakao, pisang, manggis, buangin, aren, bambu betung, dan uru, dengan populasi tanaman sebesar 540 tanaman per hektar. Pola tanam yang diterapakan masyarakat pada sistem agroforestry adalah pola acak.

Pertimbangan masyarakat di dalam memilih jenis tanaman yang ditanam dan dikembangkan pada lahan mereka adalah aspek ekonomi, konsumsi rumah tangga, dan keperluan pesta adat.

Evaluasi kesesuaian lahan dilakukan dengan menggunakan metode pencocokan (matching) yaitu membandingkan antara karakteristik/kualitas lahan dengan persyaratan tumbuhtanaman yang dievaluasi (Djaenudin dkk., 2011). Adapun jenis tanaman yang dievaluasi meliputi aren, kakao, kopi robusta, pisang, manggis, cemara gunung (buangin), cempaka hutan (Uru), dan bambu. Penilaian kesesuaian lahan dilakukan melalui dua tahapan yaitu dinilai untuk kondisi saat ini (kesesuaian lahan aktual) dan setelah diadakan perbaikan (kesesuaian lahan potensial) (Ritung dkk., 2007). Hasil evaluasi kesesuaian lahan aktual dan potensial di lokasi penelitian disajikan pada Tabel 3. 
BUDIRMAN, B. DAN RATU, MS. 2022. KARAKTERITIK LAHAN.

BIDMA ; 7(1) : 45 - 56

Tabel 3. Komposisi Jenis Tanaman dan Kesesuaian Lahan Aktual dan Potensial

\begin{tabular}{|c|c|c|c|c|c|c|c|c|c|}
\hline \multirow{2}{*}{$\begin{array}{l}\text { Parameter } \\
\text { Kesesuaian } \\
\text { Lahan }\end{array}$} & \multirow{2}{*}{$\begin{array}{l}\text { Karakteri } \\
\text { stik } \\
\text { Lokasi } \\
\text { Penelitian }\end{array}$} & \multicolumn{8}{|c|}{ Komposisi Jenis Tanaman dan Kesesuaian Lahannya } \\
\hline & & $\begin{array}{l}\text { Kopi } \\
\text { Rob } \\
\text { usta }\end{array}$ & $\begin{array}{c}\text { Kak } \\
\text { ao }\end{array}$ & $\begin{array}{c}\text { Pisan } \\
\text { g }\end{array}$ & $\begin{array}{c}\text { Mang } \\
\text { gis }\end{array}$ & $\begin{array}{c}\text { Buan } \\
\text { gin }\end{array}$ & $\begin{array}{c}\text { Are } \\
\mathrm{n}\end{array}$ & $\begin{array}{l}\text { Bam } \\
\text { bu } \\
\text { Betu } \\
\text { ng }\end{array}$ & Uru \\
\hline $\begin{array}{l}\text { Regim Suhu (t) } \\
\text { 1. Suhu Tahunanan } \\
\left({ }^{\circ} \mathrm{C}\right)\end{array}$ & $21,05^{\circ} \mathrm{C}$ & S1 & S2 & S3 & S1 & S1 & S1 & S2 & S1 \\
\hline $\begin{array}{l}\text { Ketersediaan Air } \\
(\mathrm{w}) \\
\text { 1. Bulan Kering (< } \\
75 \mathrm{~mm}) \\
\text { 2. Curah Hujan } \\
\text { Tahunan (mm) }\end{array}$ & $\begin{array}{l}2,3 \text { bulan } \\
4222,5 \\
\text { mm/tahun }\end{array}$ & $\begin{array}{l}\text { S1 } \\
\text { S2 }\end{array}$ & $\begin{array}{l}\mathrm{S} 2 \\
\mathrm{~S} 2\end{array}$ & $\begin{array}{l}\text { S3 } \\
\text { S2 }\end{array}$ & S3 & $\begin{array}{l}\text { S1 } \\
\text { S2 }\end{array}$ & S2 & $\begin{array}{l}\mathrm{S} 1 \\
\mathrm{~S} 2\end{array}$ & $\begin{array}{l}\text { S2 } \\
\text { S2 }\end{array}$ \\
\hline $\begin{array}{l}\text { Media Perakaran } \\
\text { (r) } \\
\text { 1. Drainase } \\
\text { 2. Tekstur } \\
\text { 3. Kedalaman } \\
\text { Efektif }(\mathrm{cm}) \\
\end{array}$ & $\begin{array}{l}\text { Baik } \\
\text { SCL } \\
143 \mathrm{~cm}\end{array}$ & $\begin{array}{l}\text { S1 } \\
\text { S1 } \\
\text { S2 }\end{array}$ & $\begin{array}{l}\text { S1 } \\
\text { S1 } \\
\text { S2 }\end{array}$ & $\begin{array}{l}\text { S1 } \\
\text { S1 } \\
\text { S1 }\end{array}$ & $\begin{array}{l}\text { S1 } \\
\text { S1 } \\
\text { S1 }\end{array}$ & $\begin{array}{l}- \\
- \\
-\end{array}$ & $\begin{array}{l}\text { S1 } \\
\text { S1 } \\
\text { S1 }\end{array}$ & $\begin{array}{l}\text { S1 } \\
- \\
-\end{array}$ & $\begin{array}{l}- \\
\text { S1 }\end{array}$ \\
\hline $\begin{array}{l}\text { Retensi Hara (f) } \\
\text { 1. KTK } \\
\text { 2. pH }\end{array}$ & $\begin{array}{l}\text { Tinggi } \\
5,37 \text { dan } \\
5,35\end{array}$ & $\begin{array}{l}\text { S1 } \\
\text { S2 }\end{array}$ & $\begin{array}{l}\text { S1 } \\
\text { S2 }\end{array}$ & $\begin{array}{l}\text { S1 } \\
\text { S2 }\end{array}$ & $\begin{array}{l}\text { S1 } \\
\text { S1 }\end{array}$ & S1 & S2 & $\begin{array}{l}- \\
\text { S1 }\end{array}$ & S1 \\
\hline $\begin{array}{l}\text { Ketersediaan Hara } \\
\text { (n) } \\
\text { 1. N Total } \\
\text { 2. P2O5 tersedia } \\
\text { 3. K2O tersedia }\end{array}$ & $\begin{array}{l}\text { Sedang } \\
\text { Tinggi } \\
\text { Sedang }\end{array}$ & $\begin{array}{l}\text { S1 } \\
\text { S1 } \\
\text { S1 }\end{array}$ & $\begin{array}{l}\text { S1 } \\
\text { S1 } \\
\text { S1 }\end{array}$ & $\begin{array}{l}\mathrm{S} 1 \\
\mathrm{~S} 1 \\
\mathrm{~S} 2\end{array}$ & $\begin{array}{l}\text { S1 } \\
\text { S1 } \\
\text { S1 }\end{array}$ & $\begin{array}{l}- \\
- \\
-\end{array}$ & $\begin{array}{l}- \\
- \\
-\end{array}$ & $\begin{array}{l}- \\
- \\
-\end{array}$ & $\begin{array}{l}- \\
- \\
-\end{array}$ \\
\hline $\begin{array}{l}\text { Terrain (s) } \\
\text { 1. Kemiringan } \\
\text { Lahan (\%) } \\
\text { 2. Batuan } \\
\text { Permukaan } \\
\text { 3. Singkapan } \\
\text { Batuan } \\
\end{array}$ & $\begin{array}{l}13,5 \% \\
0 \\
0\end{array}$ & $\begin{array}{l}\text { S2 } \\
\text { S1 } \\
\text { S1 }\end{array}$ & $\begin{array}{l}\mathrm{S} 2 \\
\mathrm{~S} 1 \\
\mathrm{S1}\end{array}$ & $\begin{array}{l}\text { S2 } \\
\text { S1 } \\
\text { S1 }\end{array}$ & $\begin{array}{l}\mathrm{S} 2 \\
\mathrm{~S} 1 \\
\mathrm{~S} 1\end{array}$ & $\begin{array}{l}\text { S2 } \\
- \\
-\end{array}$ & $\begin{array}{l}\text { S2 } \\
- \\
-\end{array}$ & $\begin{array}{l}\text { S2 } \\
- \\
-\end{array}$ & - \\
\hline \multicolumn{2}{|c|}{ Kesesuaian Lahan Aktual } & $\begin{array}{l}\text { S2w } \\
\text { rfs }\end{array}$ & $\begin{array}{l}\text { S2t } \\
\text { wrfs }\end{array}$ & S3tw & S3w & S2ws & $\begin{array}{c}\text { S2 } \\
\text { wfs }\end{array}$ & $\begin{array}{c}\text { S2tw } \\
\text { s }\end{array}$ & $\begin{array}{l}\text { S3 } \\
\text { ws }\end{array}$ \\
\hline \multicolumn{2}{|c|}{ Kesesuaian Lahan Potensial } & $\begin{array}{l}\text { S2w } \\
r\end{array}$ & $\begin{array}{l}\text { S2t } \\
w r\end{array}$ & S3tw & S3w & S2w & $\begin{array}{l}\text { S2 } \\
\text { w }\end{array}$ & S2tw & $\begin{array}{l}\text { S2 } \\
\text { w }\end{array}$ \\
\hline
\end{tabular}

\section{Kesesuaian Lahan Kopi Robusta (Coffea canephora)}

Berdasarkan hasil evaluasi kesesuaian lahan tanaman kopi robusta pada lokasi penelitian seperti Tabel 3 diperoleh kesesuaian lahan aktualnya termasuk cukup sesuai (S2). Faktor pembatas yang sangat mempengaruhi pertumbuhan dan produktivitas tanaman kopi di lokasi penelitian adalah iklim, khususnya curah hujan tahuanan, dimana curah hujan di lokasi penelitian yaitu $4.222,5 \mathrm{~mm} /$ tahun. Sedangkan curah hujan yang paling baik untuk kopi adalah daerah dengan curah hujan antara 2000 sampai 3000 mm/tahun (Mulyana, 1982). Faktor pembatas yang selanjutnya yaitu kedalaman efektif, pada lokasi penelitian kedalaman tanah yaitu $143 \mathrm{~cm}$ sementara kedalaman yang sesuai untuk kopi adalah $>150$ $\mathrm{cm}$.

Faktor berikutnya yaitu $\mathrm{pH}$ tanah, di lokasi penelitian yaitu 5,36 dan 5,37 sementara untuk persyaratan tumbuh kopi $\mathrm{pH}$ yang paling sesuai yaitu berkisar $5,5-6,5$. Meskipun $\mathrm{pH}$ 
di lokasi tidak sesuai tapi masih cukup sesuai untuk ditanami kopi robusta. Faktor selanjutnya yang cukup berpengaruh adalah kemiringan lahan dimana kemiringan lahan di lokasi penelitian sebesar $13,5 \%$ sedangkan tanaman kopi robusta akan tumbuh baik pada kisaran lereng < 8\% (Djaenuddin, dkk., 2003).

Guna meningkatkan kesesuaian lahan dibutuhkan beberapa perbaikan pada kualitas lahan. Perbaikan untuk pH dengan menaikkan $\mathrm{pH}$ menggunakan kapur atau penambahan bahan organik, untuk kemiringan lahan dapat dilakukan usahan perbaikan berupa tindakan konservasi tanah seperti pembuatan teras dan penanaman sejajar kontur. Kesesuian lahan potensial kopi pada lokasi penelitian tetap S2 dikarenakan kedalaman efektif dan curah hujan merupakan faktor pembatas yang bersifat permanen.

\section{Kesesuaian Lahan Kakao (Theobroma cacao)}

Berdasarkan hasil evaluasi kesesuaian lahan tanaman kakao dapat diketahui kesesuaian lahan aktualnya yaitu cukup sesuai (S2). Faktor Regim suhu yaitu suhu tahunan dimana pada lokasi penelitian suhunya sebesar $21,05^{\circ} \mathrm{C}$. Sementara suhu yang paling sesuai untuk kakao yaitu berkisar $25-28^{\circ} \mathrm{C}$. Suhu yang rendah dapat mempengaruhi pembungaan dan kerusakan daun. Hal ini juga sejalan dengan Liyanda, dkk., (2012) bahwa suhu yang terlalu rendah bisa menghambat pembentukan bunga dan perkembangan tanaman kakao. Faktor pembatas berikutnya yaitu karakteristik curah hujan, dimana curah hujan di lokasi penelitian yaitu $4.222,5 \mathrm{~mm} /$ tahun. Sementara curah hujan yang ideal untuk tanaman kakao yaitu berkisar $1.500-2.500 \mathrm{~mm} /$ tahun (Wahyudi, 2009). Dengan curah hujan ini diduga dapat mempengaruhi produksi dari tanaman kakao. Hal ini juga sejalan dengan yang dikatakan Ajayi, dkk., (2010) dalam Tjahjana, dkk., (2014) yang menyebutkan bahwa curah hujan yang berlebih dapat berdambak buruk terhadap kakao, seperti mengurangi penyinaran marahari, mengurangi pembungaan serta meningkatkan terjadinya busuk pada buah kakao (BBK) yang secara langsung dapat menurunkan produksi buahnya. Selain curah hujan, bulan kering juga menjadi faktor pembatas karena memiliki bulan kering 2,3 bulan sedangkan tanaman kakao tumbuh sesuai dengan bulan kering $1-2$ bulan.

Faktor pembatas lainnya yaitu kedalaman efektif, di lokasi penelitian kedalaman sebesar $143 \mathrm{~cm}$ namun yang sesuai yaitu sebesar $>150 \mathrm{~cm}$. Selanjutnya yaitu $\mathrm{pH}$ tanah, untuk lokasi penelitian nilai $\mathrm{pH}$ yang didapatkan yaitu 5,37 dan 5,35 namun menurut Hardjowigeno dan Widiatmaka (2007) pH yang sesuai untuk tanaman kakao yaitu 5,5 - 6,5. dan faktor pembatas yang terakhir yaitu kemiringan lahan. Kemiringan lahan yang ada pada lokasi yaitu $13,5 \%$, namun kemiringan lahan yang sesuai yaitu $<8 \%$.

Guna meningkatkan kesesuaian lahan dibutuhkan beberapa perbaikan pada kualitas lahan. Kemiringan lahan dapat dilakukan adalah dengan melakukan usaha/tindakan konservasi tanah, misalnya pengurangan laju erosi dengan pembuatan terras atau guludan, penanaman sejajar kontur, pengolahan tanah menurut kontur, penanaman penutup tanah, dan lain sebagainya. Namun kelas kesesuaian lahan kakao tetap S2 karena faktor pembatas suhu, curah hujan, bulan kering dan media perakaran dimana karakteristik lahan diatas tidak dapat dilakakukan usaha perbaikan karena sangat sulit untuk dapat merubahnya.

\section{Kesesuaian Lahan Pisang (Musa paradisiaca)}

Berdasarkan hasil evaluasi kesesuaian lahan tanaman pisang dapat diketahui kesesuaian lahan aktualnya yaitu Sesuai Marginal (S3). Suhu tahunan dan bulan kering. Berdasarkan Tabel 3 suhu tahunanannya $21,05^{\circ} \mathrm{C}$, sedangkan menurut CSR/FAO (1983) suhu udara yang sesuai untuk tanaman pisang yaitu $25^{\circ} \mathrm{C}-27^{\circ} \mathrm{C}$. Hal ini dapat terjadi karena ketinggian dilokasi penelitian yaitu 876 mdpl sehingga suhu yang dihasilkan rendah sehingga menyebabkan terhambatnya pertumbuhan dari tanaman pisang. Sastry (1988) mengungkapkan bahwa tanaman pisang yang tumbuh pada suhu di bawah $15,5{ }^{\circ} \mathrm{C}$ menyebabkan perkembangan daun pisang terhambat dan pematangan buah terlambat. Kemudian untuk faktor pembatas berikutnya yaitu bulan kering dimana bulan kering di lokasi 
penelitian yaitu 2,3 bulan namun bulan kering yang optimal untuk tanaman pisang yaitu kurang dari 1 bulan.

Kesesuaian lahan potensial untuk tanaman pisang sendiri tetap berada pada kelas kesesuaian lahan S3 karena faktor suhunya yang sangat berpengaruh dan sulit untuk dapat memperbaikinya sehingga tetap berada pada kelas S3. Selain itu juga untuk bulan keringnya sama seperti suhu sulit untuk dapat melakukan perbaikan.

\section{Kesesuaian Lahan Manggis (Garcinia mangostana)}

Berdasarkan hasil evaluasi kesesuaian lahan tanaman manggis dapat diketahui kesesuaian lahan aktualnya yaitu Sesuai Marginal (S3). Curah hujan tahunan, dimana curah hujan tahunan di lokasi penelitian yaitu $4.222,5 \mathrm{~mm} /$ tahun sedangkan menurut Aprisal (2012) tanaman manggis dapat tumbuh dengan baik pada daerah mempunyai jumlah curah hujan pertahun sekitar $700-2.500 \mathrm{~mm}$. Curah hujan pada lokasi tidak sesuai karena intensitasnya yang cukup tinggi tapi untuk tanaman manggis juga membutuhkan curah hujan yang cukup untuk menyerap unsur-unsur hara dari dalam tanah. Hal ini sejalan dengan Fiantis (2001) curah hujan yang merata maka ketersediaan air mencukupi untuk pertumbuhan tanaman manggis. Kesesuaian lahan potensial untuk menggis tetap S3 karena faktor curah hujan yang sulit untuk dapat dilakukan usaha perbaikan.

\section{Kesesuaian Lahan Buangin (Casuarina junghuniana)}

Berdasarkan hasil evaluasi kesesuaian lahan tanaman buangin dapat diketahui kesesuaian lahan aktualnya yaitu cukup sesuai (S2). Ketersediaan air termasuk S2 karena curah hujannya yaitu $4.222,5 \mathrm{~mm} /$ tahun sementara curah hujan yang sesuai untuk tanaman buangin yaitu menurut Orwa, dkk., (2009), tanaman buangin dapat tumbuh pada daerah yang memiliki curah hujan dari 700 sampai $2.000 \mathrm{~mm} /$ tahun. Namun menurut Indonesia Eagle (2014), sifat cemara gunung mampu bertahan dalam genangan air yang berkepanjangan serta dalam kondisi cuaca buruk. Faktor pembatas berikutnya yaitu kemiringan lahan dengan nilai $13,5 \%$ atau bergelombang. Sedangkan yang sesuai adalah $<8 \%$.

Guna meningkatkan kesesuaian lahan menjadi kesesuaian lahan potensial dibutuhkan perbaikan, karakteristik lahan berupa kemiringan lahan dapat dilakukan usaha perbaikan berupa pembuatan teras, penanaman sejajar kontur dan penanaman tanaman penutup tanah. Sedangkan untuk curah hujan tidak dapat dilakukan usaha perbaikan sehingga kelas kesesuaian lahan buangin tetap S2.

\section{Kesesuaian Lahan Aren (Arenga pinnata)}

Berdasarkan hasil evaluasi kesesuaian lahan tanaman aren dapat diketahui kesesuaian lahan aktualnya yaitu Sesuai Marginal (S2). Curah hujan yaitu sebesar 4.222,5 $\mathrm{mm} /$ tahun, sedangkan menurut Effendi (2010) tanaman aren sangat cocok ditanam pada curah hujan antara $1200-3500 \mathrm{~mm} / \mathrm{thn}$. Curah hujan pada lokasi penelitian termasuk tinggi sehingga diduga dapat menghambat masa perbunga dan berbuah dari aren. Effendi (2010) menyatakan bahwa pembentukan mahkota tanaman diperlukan curah hujan $1.200-3.500$ $\mathrm{mm} /$ tahun agar kelembaban tanaman dapat dipertahankan, sehingga dengan curah hujan tersebut diduga dapat menghambat pembentukan mahkota. Faktor berikunya yaitu $\mathrm{pH}$ tanah, dimana $\mathrm{pH}$ tanah di lokasi penelitian yaitu 5,37 dan 5,36 namun $\mathrm{pH}$ yang sesuai untuk aren ialah 5,5 -6,5. Faktor berikut yaitu kemiringan lahan yaitu $13,5 \%$, namun menurut Effendi (2010) tanaman aren sangat cocok ditanam pada kondisi lahan yang landai. Puturuhu, dkk. (2011) mengatakan tanaman aren dapat tumbuh pada berbagai kelas lereng.

Guna meningkatkan kesesuaian lahan dibutuhkan perbaikan pada kualitas lahan. Perbaikan yang dapat dilakukan yaitu pengapuran untuk menaikkan $\mathrm{pH}$ tanah dan penamanan sejajar kontur dan pembuatan teras pada lokasi penelitian. Curah hujan tidak dapat dilakukan usaha perbaikan sehingga tetap kesesuaian lahannya menjadi S2. 


\section{Kesesuaian Lahan Bambu Betung (Dendrocalamus asper)}

Berdasarkan hasil evaluasi kesesuaian lahan tanaman bambu betung dapat diketahui kesesuaian lahan aktualnya yaitu Sesuai Marginal (S2). Suhu menjadi salah satu faktor penghambat untuk bambu betung. Meskipun suhu yang paling optimum untuk bambu betung adalah $25-28^{\circ} \mathrm{C}$ namun tanaman bambu betung masih cukup sesuai tumbuh dengan baik pada lokasi walaupun suhunya $21,05^{\circ} \mathrm{C}$. Hal ini juga diungkapkan Sutiyoso, dkk., (1996) yang menyebutkan suhu udara yang cocok untuk perumbuhan bambu betung berkisar $8,8-36^{\circ} \mathrm{C}$. Faktor pembatas berikut yaitu karaktristik curah hujan dimana curah hujannya yaitu $4.222,5 \mathrm{~mm} /$ tahun sedangkan tanaman bambu betung dapat tumbuh baik dengan curah hujan $<2.400 \mathrm{~mm} /$ tahun. Curah hujan yang tinggi ini untuk bambu betung kurang sesuai karena bambu betung menyukai lahan yang kering. Hal ini juga diungkapkan Fauzi (2016) bahwa bambu betung termasuk jenis tidak tahan genangan air sehingga jika dibudidayakan harus dipilih di lahan kering. Faktor penghambat berikutnya adalah kemiringan lahan, untuk kemiringan lahan di lokasi yaitu 13,5\% dan untuk kemiringan lahan yang sesuai untuk bambu betung adalah $<8 \%$. Namun berdasarkan Sastrapradja, dkk., (1977) kebutuhan untuk budidaya tanaman bambu, bambu dapat tumbu pada tiga bentuk topografi, dari berombak, bergelombang, sampai bergunung.

Guna meningkatkan kesesuaian lahan dibutuhkan perbaikan pada kualitas lahan. Untuk karakteristik kemiringan lahan dapat dilakukan usaha perbaikan yaitu penerapan sistem konservasi tanah untuk mengatasi kemiringan lahan yang kurang sesuai seperti penanaman sejajar kontur. Selain itu terdapat faktor pembatas lain yang termasuk S2 yaitu suhu tahunan dan curah hujan, namun keduanya tidak dapat dilakukan usaha perbaikan sehingga kesesuaian lahan potensialnya termasuk Cukup Sesuai (S2).

\section{Kesesuaian Lahan Uru (Elemerillia ovalis)}

Berdasarkan hasil evaluasi kesesuaian lahan tanaman cempaka hutan atau uru dapat diketahui kesesuaian lahan aktualnya yaitu cukup sesuai (S2). Curah hujan tahunan menjadi salah satu faktor pembatas karena memiliki curah hujan yang cukup tinggi, dimana curah hujan uru menurut kriteria evaluasi lahan memiliki curah hujan yang berkisar $1.400-2.600$ $\mathrm{mm}$ /tahun. Curah hujan memang termasuk kurang sesuai namun menurut Musriati, dkk., (2004) Uru termasuk tanaman yang dapat hidup pada tanah yang lembab. Berikutnya adalah kemiringan lahan namun kemiringan lahan untuk uru masuk kedalam kelas S2 jadi masih sesuai untuk ditanami.

Guna meningkatkan kesesuaian lahan dibutuhkan perbaikan pada kualitas lahan. Perbaikan yang dapat dilakukan yaitu penerapan sistem konservasi tanah seperti penambahan tanaman penutup tanah, menambahakan tanaman penguat teras dan pembuatan teras untuk mencegah terjadinya erosi. Curah hujan sulit untuk dapat dilakukan usaha perbaikan sehingga kesesuaian lahannya tetap S2.

\section{Kesimpulan}

Berdasarkan hasil penelitian dapat disimpulkan: 1) Komposisi jenis tanaman penyusun komponen agroforestry pada Kecamatan Sesean adalah kopi (Coffea canephora), kakao (Theobroma cacao), uru (Elemerillia ovalis), buangin (Casuarina junghuniana), pisang (Musa paradisiaca), manggis (Garcinia mangostana), bambu (Dendrocalamus asper), dan aren (Arenga pinnata). 2) Kelas kesesuian lahan untuk jenis kopi, kakao, buangin, aren, bambu, dan uru adalah cukup sesuai (S2). Sedangkan kelas kesesuaian lahan untuk jenis manggis dan pisang termasuk sesuai marginal (S3). 


\section{Daftar Pustaka}

Anifuddin, A., B. H. Sunarmito, M. D. Renanti. 2006. Evaluasi Kesesuaian Lahan Untuk Budidaya Tanaman Pangan Menggunakan Jaringan Syaraf Tiruan. Berkala MIPA. 16 (1): 4.

Aprisal. 2012. Survai kesesuaian lahan untuk tanaman manggis (Garcinia mangostana L) sebagai tanaman konservasi di kabupaten limapuluh kota sumatera barat. Jurnal Solum, 9 (2): 69-76.

Bey, A dan I, Las. 1991. Strategi Pendekatan Iklim dalam Usaha Tani dalam Kapita Selekta dalam agrometeorologi. Dirjen Pendidikan Tinggi Depdikbud. Jakarta

Braak, C. 1928. The Climate of The Netherlands Indies. Proc. Royal Mogn. Meteor.Observ. Batavia, 14: 192.

CSR/FAO. 1983. Recconnaissance Land Resources Surveys 1:250.000 Scale. Atlas Format Procedures. Manual 4, Version 1. Center for Soil Research, Ministry of Agriculture Government of Indonesia - United Nations Development Programme and Food and Agriculture Organization. Bogor. Indonesia.

Djaenuddin, D., M. Herdriman, H. Subagyo, A. Mulyani dan N. Suharta. 2003. Kriteria Kesesuain Lahan Untuk Komoditas Pertanian. Versi 4: Januari 2003. Balai Penelitian Tanah. Pusat Penelitian Tanah dan Pengembanagan Tanah dan Agroklimat. Bogor.

Djaenudin, D., Marwan., Subagjo., dan A. Hidayat. 2011. Petunjuk Teknis Evaluasi Lahan untuk Komoditas Pertanian. Balai Penelitian Tanah, Puslitbangtanak, Bogor.

Effendi D.S.. 2010. Prospek pengembangan tanaman aren (Arenga pinnata Merr) mendukung kebutuhan bioetanol di Indonesia. Perspektif, 9 (1): 36-46.

Fauzi, A.T. 2016. Identifikasi Potensi Kawasan Pengembangan Budidaya Tanaman Bambu di Kabupaten Gunung Kidul (Studi Kasus di Kecamatan Playen). Skripsi. Universitas Muhammadiyah Yogyakarta.

Fiantis, D. 2001. Pengembangan Sistem Informasi Geografi Tanah Vulkanis Sumatera Barat untuk Peningkatan Produksi Tanaman Hortikultura. Proposal Riset Unggulan Terpadu IX. Universitas Andalas. Padang.

Hairiah, K.,M. A. Sardjono dan M. S. Sabarnurdin. 2003. Pengantar Agroforestri. Indonesia World Agroforestry Centre (ICRAF).Bogor, Inonesia.

Handayani, W., A. Sudomo. 2004. Evaluasi Kesesuaian Lahan Jenis-Jenis Tanaman Hutan Rakyat Agroforestry di Desa Tenggeraharja, Kecamatan Sukamatri, Kabupaten Ciamis, Provinsi Jawa Barat. Prosiding Seminar Nasional Agroforestry 2013 "Agroforestry untuk Pangan dan Lingkungan yang Lebih Baik". Balai Penelitian Agroforestry, Fakultas Pertanian Universitas Brawijaya, World Agroforestry Center (ICRAF), dan Masyarakat Agroforestry Indonesia, Malang.

Hardjowigeno, S. dan Widiatmaka. 2007. Evaluasi Kesesuaian Lahan dan Perencanaan Tata Guna Lahan. Gadjah Mada University Press. Yogyakarta.

Indonesia Eagle. 2014. 5W + $1 \mathrm{~W}$ Cemara Gunung. Indonesiaeagle.blogspot.co.id/2014/12/5w-1h-cemara gunung-html. Diakses pada tanggal 9 Mei 2018.

Klingebiel, A.A., and P.H. Montgomery. 1961. Land Capability Classification Agric. Handb. No. 210, SCS-USDA. Washington.

Liyanda, M., A. Karim., dan Y. Abubakar. 2012. Analisi kriteria Kesesuian Lahan Terhadap Produksi Kakao pada Tiga Klaster Pengembangan di Kabupaten Pidie. Jurnal Agrista, 16 (2): $62-79$.

Mukhlis. 2007. AnalisisTanah dan Tanaman. USU Press. Medan. $155 \mathrm{Hal}$

Musriati. Nujarmudin. Hartati, R, A.. dan HD, D, A.. 2004. Informasi Singkat Behih E. ovalis. Direktorat Pembenihan Tanaman Hutan.

Orwa, C., Mutua, A., Kindt, R., Jamnadass, R and Simons, A., 2009, Agroforestree Database: a free reference and selectioan guide version 4.0, http:// www.agroforestry.org/af/treedb, Diakses pada 15 Mei 2018. 
Puturuhu, F., J. Riry., dan A.J.Ngingi. 2011. Kondisi Fisik Lahan Tanaman Aren (Arenga pinnata L.) di Desa Tuhaha Kecamatan Saparu Kabupaten Maluku Tengah. Jurnal Budidaya Pertanian, 7(2) 94-99.

Ritung, S., Wahyunto, F. Agus, H. Hidayat. 2007. Panduan Evaluasi Kesesuaian Lahan dengan Contoh Peta Arahan Penggunaan Lahan Kabupaten Aceh Barat. Balai Penelitian Tanah dan World Agroforestry Centre (ICRAF), Bogor, Indonesia.

Sanchez PA. 1993. Sifat dan Pengelolaan Tanah Tropika Jilid 2. Amir Hamzah (penerjemah). ITB, Bandung.

Sastrapradja S., Wiidjaja E, A, Prawiroatmodjo, Soekarno S. 1997. Beberapa Jenis Bambu. Bogor: Lembaga Biologi Nasional-LIPI.

Sastry, P.S.N. 1988. Agrometeorology of the Banana Crop. World Meterological Organization. Geneva.

Setianingrum, L. 2011. Evaluasi Kesesuaian Lahan Untuk Tanaman Tebu dan Kacang tanah di Kecamatan Jenar kabupaten Sragen tahun 2010. Skripsi. Universitas Sebelas Maret, Surakarta.

Subandi, M. 2011. Budidaya Tanaman Perkebunan (Bagian Tanaman Kopi). Gunung Jati Press. Bandung.

Sutiyoso, Hendramono, Marfu'ah, Ihak. 1996. Teknik Budidaya Tanaman bambu. Pusat Litbang hasil Hutan, Bogor. Diakses pada tanggal 20 Mei 2018.

Tufaila, M., Aliyaman, S. Ginting, S. Alam. 2014. Evaluasi Kesesuaian Lahan Untuk Tanaman Kopi, Kakao, Dan Jambu Mete Di Kecamatan Moramo Utara Kabupaten Konawe Selatan. Jurnal Agroteknos. 4 (3) :167-173.

Wahyudi .T. 2009. Panduan Lengkap Kakao. Penebar Swadaya.364 Hal

Wibowo C. 2008. Diktat Pelatihan Budidaya Gaharu. Bogor (ID): Fakultas Kehutanan Institut Pertanian Bogor.

Yanis, N. M., H. Guchi, dan M. Sembiring. 2014. Evaluasi Kesesuaian Lahan Kabupaten Dairi untuk Tanaman Kopi Robusta (Coffea robusta Lindl). Jurnal Online Agroekoteknologi, (2 (4):1464-1478. 